\title{
Analisis Rasio Profitabilitas Pada CV Surya Indah Perkasa Di Tanjung Redeb
}

\author{
Dawami Buchori \\ Manajemen, Ekonomi dan Bisnis, Universitas Muhammadiya Berau, Tanjung Redeb, \\ Email: dawamibuchori80@gmail.com
}

\begin{abstract}
The purpose of this study was to determine whether the profitability ratio of CV Surya Indah Perkasa in Tanjung Redeb in 2020 has increased compared to 2019. The usefulness of the results of this study is as information for management to determine company policies related to increasing company profitability in the future. The analytical tool used in this research is the Profitability Ratio, namely Gross Profit Margin, Operating Profit Margin and Net Profit Margin. Based on the results of the study, it can be seen that the comparison of Profitability Ratios in CV Surya Indah Perkasa in Tanjung Redeb in 2020 with 2019 showing that Gross Profit margin in 2020 increased by 0.67\%, Operating Profit Margin in 2020 increased by 3.39\%, Net Profit Margin in 2020 increased by $2.97 \%$. Based on these results, the proposed hypothesis is accepted.
\end{abstract}

Keywords: Analysis, Ratio, Profitability

\begin{abstract}
Abstrak
Tujuan penelitian ini adalah untuk mengetahuai apakah rasio profitabilitas CV Surya Indah Perkasa di Tanjung Redeb pada tahun 2020 mengalami peningkatan dibandingkan tahun 2019. Adapun kegunaan hasil penelitian ini adalah sebagai informasi bagi pihak manajemen untuk menentukan kebijakan perusahaan yang berkaitan untuk meningkatkan profitabilitas perusahaan dimasa yang akan datang. Alat analisis yang digunakan dalam penelitian ini adalah Rasio Profitabilitas yaitu Gross Profit Margin, Operating Profit Margin dan Net Profit Margin. Berdasarkan hasil penelitian dapat diketahui bahwa perbandingan Rasio Profitabilitas pada CV Surya Indah Perkasa di Tanjung Redeb tahun 2020 dengan tahun 2019 menunjukkan bahwa Gross Profit margin tahun 2020 naik sebesar 0,67\%, Operating Profit Margin tahun 2020 naik sebesar 3,39\%, Net Profit Margin tahun 2020 naik sebesar 2,97\%. Berdasarkan hasil tersebut maka hipotesis yang diajukan diterima.
\end{abstract}

Kata Kunci: Analisa, Rasio, Profitabilitas

\section{PENDAHULUAN}

Pada saat ini persaingan bisnis terjadi dimana-mana, persaingan ini terjadi karena keadaan perekonomian yang semakin sulit dimasa yang sekarang. Setiap perusahaan harus saling berlomba untuk terus maju dan memperbaiki kekurangan perusahaan agar dapat bersaing dan berlomba 
untuk mendapatkan pangsa pasar. Perusahaan harus dapat bertahan dan bersaing dengan perusahaan lain untuk mewujudkan tujuan perusahaan tersebut namun dengan cara yang efektif dan efisien karena pada saat ini sedang berada di dalam situasi perekonomian globalisasi.

Indonesia merupakan suatu wilayah yang kaya dan iklim yang mendukung. Banyaknya kekayaan yang Indonesia miliki akan menghasilkan penghasilan untuk masyarakat dan perusahaan yang mengelolah salah satunya kekayaan dari lautnya. Budidaya perikanan seperti tambak udang, bandeng, kerapu dan jenis lainnya menjadi alternative usaha yang dapat dikembangkan diwilayah pesisir. Terkhusus udang merupakan salah satu komuditas ekspor unggulan yang perlu ditingkatkan baik dari segi kualitas dan kuantitasnya.

Kondisi lingkungan dalam tambak menjadi salah satu permasalahan yang utama dikarenakan kebutuhan hidup udang sangat bergantung pada lingkungan tambak. Tidak sedikit masyarakat pesisir beralih profesi dari nelayan tangkap menjadi petambak karena usaha budidaya ini memberikan keuntungan yang cukup besar.

Bagi pihak manajemen keuntungan yang diperoleh merupakan pencapaian yang telah ditentukan sebelumnya dan juga sebagai prestasi bagi pihak manajemen karena memenuhi target. Seluruh kegiatan perusahaan diharapkan mampu memberikan informasi dan laporan akan seluruh kegiatan dalam suatu periode yang telah ditentukan karena laporan tersebut akan sangat berguna bagi pihak manajemen karena dapat digunakan sebagai bahan evaluasi suatu perusahaan.

Manajemen keuangan sangat berpengaruh penting terhadap kelangsungan kegiatan suatu perusahaan. Kinerja keuangan perusahaan menjadi gambaran atas keadaan kondisi keuangan suatu perusahaan pada periode tertentu. Perlunya dilakukan analisis laporan keuangan sebagai bentuk penilaian terhadap kinerja suatu perusahaan dalam waktu tertentu. Alat analisis keuangan yang biasa digunakan adalah rasio-rasio keuangan.

Rasio keuangan merupakan kegiatan membandingkan angka-angka yang ada dalam laporan keuangan dengan cara membagi satu angka dengana angka lainnya. Hasil rasio keuangan digunakan untuk menilai kinerja keuangan manajemen dalam suatu periode. Setiap rasio akan memberikan makna tersendiri dalam menggambarkan kondisi keuangan perusahaan.

Rasio profitabilitas merupakan rasio yang digunakan untuk mengukur kemampuan perusahaan dalam menghasilkan laba dari aktivitas normal bisnisnya. Rasio ini bertujuan untuk mengetahui kemampuan perusahaan dalam menghasilkan keuntungan pada periode tertentu dan juga digunakan sebagai alat dalam mengukur tingkat efektivitas manajemen untuk menjalankan operasional perusahaan.

Rasio profitabilitas dapat digunakan sebagai alat untuk mengukur 
tingkat efektivitas kinerja manajemen dengan kinerja yang baik akan ditunjukkan lewat keberhasilan manajemen dalam menghasilkan laba yang maksimal bagi perusahaan. Pengukuran rasio profitabilitas dapat dilakukan dengan membandingkan antara berbagai komponen yang ada didalam laporan laba rugi, pengukuran dapat dilakukan untuk beberapa periode.

Berdasarkan hasil obeservasi prapenelitian, peneliti memperoleh informasi sampai saat ini pihak manajemen CV Surya Indah Perkasa di Tanjung Redeb belum pernah mengukur seberapa besar tingkat kemampuan perusahaan tersebut dalam menghasilkan laba.

Untuk mencari jawaban terhadap permasalahan tersebut diatas, peneliti bermaksud mengadakan suatu penelitian dan menyusun hasilnya dalam sebuah penelitian yang peneliti beri judul : "Analisis Rasio Profitabilitas pada CV Surya Indah Perkasa di Tanjung Redeb”.

Penilaian atas profitabilitas operasional perusahaan sebagian besar dilakukan berdasarkan Analisa atas laporan laba rugi, untuk menilai profitabilitas ini menggunakan beberapa rasio antara lain alat analisis yang digunakan ialah Gross Profit Margin, Net Profit Margin dan Operating Profit Margin.

Berdasarkan pendahuluan yang telah penulis uraikan tersebut maka dapat penulis kemukakan bahwa perumusan masalah dalam penelitian ini yaitu: "Apakah rasio profitabilitas CV Surya Indah Perkasa pada tahun 2020 mengalami peningkatan dibandingkan tahun 2019 ?".

\section{KAJIAN TEORI}

\section{Pengertian Manajemen}

Management berasal dari kata to manage yang artinya mengatur dan manajemen juga digunakan untuk menganalisa dalam penetapan tujuan yang diinginkan dimana tujuan tersebut dapat tercapai dengan efektif dan efisien. Secara umum aktivitas manajemen ada dalam organisasi yang diarahkan untuk mencapai tujuan organisasi secara efektif dan efisien. Adapun 7 unsur manajemen yaitu manusia, uang, bahan baku, mesin, metode dalam proses, pasar dan waktu.

Menurut Terry (2010:16) mengemukakan bahwa manajemen adalah suatu proses yang didasarkan oleh perencanaan, pengorganisasian, pengarahan dan pengendalian sebagai proses penentuan untuk mencapai tujuan dengan memanfaatkan sumber daya manusia dan lainnya.

Menurut Hasibuan (2012:1) mengemukakan bahawa manajemen adalah seni dan ilmu yang mengatur suatu proses dalam memanfaatkan sumber daya manusia dan sumber lainnya dengan efisien dan efektif untuk mencapai target yang sudah ditentukan.

Menurut Sulastri (2014:14) mengemukakan bahwa manajeman merupakan seni yang didalamnya terdapat proses, cara serta tindakan yaitu perencanaan, pengorganisasia, pengarahan dan pengawasan Tindakan ini dilakukan untuk mencapai tujuan yang diinginkan secara efisien dan efektif. 
Berdasarkan definisi para ahli diatas peneliti mengambil kesimpulan bahwa manajemen adalah seni dan ilmu yang mengatur suatu proses yang didalamnya terdapat perencanaan, pengorganisasian, pengarahan dan pengawasan hal ini dilakukan untuk mencapai tujuan yang diinginkan dengan efektif dan efisisen.

\section{Pengertian Manajemen Keuangan}

Manajamen keuangan sangat penting dalam proses keuangan perusahaan yang berhubungan dengan upaya untuk mendapatkan dana perusahaan dan meminimalkan biaya perusahaan serta upaya pengelolaan keuangan suatu badan usaha atau organisasi untuk mencapai tujuan keuangan yang telah ditetapkan. Manajamen keuangan membahas tentang pengelolaan keuangan yang pada dasarnya dapat dilakukan oleh individu, perusahaan maupun pemerintah.

Manajamen keuangan mempunyai hubungan yang erat didalam seluruh proses manajemen ini dikarenakan peranan pokok manajemen keuangan mempunyai sasaran yang sama dengan manajamen itu sendiri yaitu cara penggunaan sumber perusahaan dan cara pembiayaan.

Menurut Horne dan Wachowicz (2012:2) mengemukakan bahwa manajemen keuangan adalah aktivitas yang berkaitan dengan pendanaan, pengelolaan dan perolehan asset yang didasarkan pada tujuan.

Menurut Fahmi (2014:2) mengemukakan bahwa manajemen keuangan merupakan seni dan ilmu yang megkaji dan membahas tentang bagaimana seorang manajer mengkoordinasi sumber daya perusahaan untuk mencari dan mengelola dana dengan tujuan memberikan profit.

Menurut Musthafa (2017:3) mengemukakan bahwa manajemen keuangan adalah beberapa keputusan yang harus diambil oleh manajer seperti keputusan investasi, keputusan kebijakan deviden dan keputusan pemenuhan dana.

Berdasarkan pengertian para ahli diatas dapat disimpulkan bahwa manajemen keuangan adalah suatu aktivitas yang berkaitan mengenai pengambilan suatu keputusan untuk mengelola dana dan menggunakan dengan efisien.

\section{Rasio Keuangan}

Rasio keuangan menggambarkan suatu hubungan antar jumlah tertentu dan jumlah lain dengan menggunakan alat analisis berupa rasio dapat memberi gambaran mengenai baik buruknya posisi keuangan perusahaan apabila angka rasio dibandingkan dengan angka rasio pembanding yang digunakan sebagai standard. Standard rasio digunakan sebagai pedoman atau pegangan bagi penganalisa.

Menurut Harahap (2018:297) rasio keuangan adalah angka yang diperoleh dari hasil perbandingan dari satu pos laporan keuangan dengan pos lainnya yang mempunyai hubungan yang relevan dan signifikan.

Menurut Kasmir (2019:104) mengemukakan bahwa rasio keuangan merupakan kegiatan membandingkan angka-angka yang ada dalam laporan keuangan dengan cara membagi satu angka dengan angka lainnya dan perbandingan dilakukan antara satu komponen dengan komponen dalam satu laporan keuangan atau antarkomponen yang ada diantara laporan keuangan.

Berdasarkan definisi para ahli diatas disimpulkan bahwa rasio keuangan adalah kegiatan membandingkan angka-angka yang ada pada laporan keuangan, angka yang berada di satu periode maupun beberapa periode. 


\section{Bentuk-bentuk Rasio Keuangan}

Untuk mengukur kinerja keuangan perusahaan dengan menggunakan rasio rasio keuangan, dapat dilakukan dengan bebrapa rasio keuangan. Kemudian, setiap hasil dari rasio yang diukur diinterpretasikan sehingga menjadi berarti bagi pengambilan keputusan. Menurut Harahap (2018:301) berikut ini adalah bentuk bentuk rasio keuangan :

a. Rasio Likuiditas adalah rasio yang menggambarkan kemampuan perusahaan dalam menyelesaikan kewajiban jangka pendeknya rasio ini dapat dihitung melalui sumber informasi modal kerja yaitu aktiva lancar dan hutang lancar.

b. Rasio Solvabilitas adalah rasio yang menggambarkan kemampuan perusahaan dalam membayar kewajiban jangka panjang rasio dapat dihitung melalui aktiva tetap dan utang jangka panjang yang bersifat jangka panjang.

c. Rasio Aktivitas adalah rasio yang menggambarkan aktivitas yang dilakukan perusahaan dan menjalankan operasinya dalam kegiatan penjualan dan pembelian.

d. Rasio Profitabilitas adalah rasio yang menggambarkan kemampuan perusahaan mendapatkan laba melalui aktivitas-aktivitas yang dilakukan perusahaan seperti penjualan, kas, modal, dan jumlah cabang.

\section{Rasio Profitabilitas}

Tujuan akhir yang ingin dicapai suatu perusahaan adalah memperoleh laba. Dengan memperoleh laba yang maksimal seperti yang ditargetkan perusahaan dapat berbuat banyak bagi kesejahteraan pemilik, karyawan, serta meningkatkan mutu produk. Oleh karena itu, manajemen perusahaan dalam praktiknya dituntut harus mampu untuk memenuhi target yang telah ditetapkan. Untuk mengukur tingkat keuntungan suatu perusahaan digunakan rasio keuntungan yang dikenal juga dengan rasio profitabilitas.

Menurut Kasmir (2019:198) mengemukakan bahwa rasio profitabilitas adalah rasio untuk menilai kemampuan perusahaan dalam mencari keuntungan dimana rasio ini memberikan ukuran tingkat efektivitas manajemen suatu perusahaan yang ditunjukkan oleh laba yang dihasilkan dari penjualan dan pendapatan investasi.

Menurut Munawir (2014:86) mengemukakan bahwa rasio profitabilitas adalah rasio yang digunakan dalam mengukur keuntungan yang diperoleh dari modal-modal yang digunakan untuk operasi tersebut atau mengukur kemampuan perusahaan untuk memperoleh keuntungan.

Berdasarkan definisi para ahli diatas dapat disimpulkan bahwa rasio profitabilitas adalah rasio untuk menilai kemampuan suatu perusahaan dalam mencari keuntungan dan mengukur tingkat efektivitas manajemen. Sesuai dengan firman Allah SWT di surah Al-Hasry 18 ;

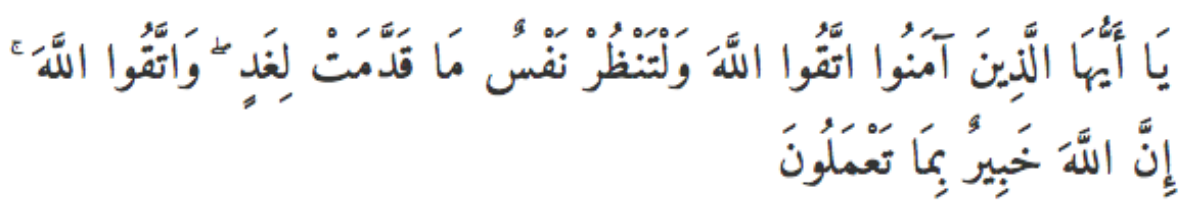

Artinya : Hai orang-orang yang beriman bertaqwalah kepada Allah SWT dan hendaklah setiap diri memperhatikan apa yang telah diperbuatnya untuk hari esok akhir dan bertaqwalah kepada Allah SWT, sesungguhnya Allah maha mengetahui apa yang kamu kerjakan. 
Evaluasi kinerja salah satunya dengan melihat laporan keuangan dengan menggunakan rasio keuangan dimasa lalu, saat ini dan kemungkinannya dimasa datang, dengan kebijakan yang lama dijadikan pembelajaran untuk mengambil kebijakan yang baru yang lebih baik dan sesuai dengan perusahaan.

\section{Tujuan Rasio Profitabilitas}

Rasio profitabilitas memiliki tujuan dan tidak hanya bagi pihak pemilik usaha dan manajemen tetapi juga bagi pihak di luar perusahaan terutama pihak-pihak yang memiliki kepentingan dengan perusahaan. Menurut Kasmir (2019:199) tujuan penggunaan rasio profitabilitas yaitu:

a. Untuk mengukur atau menghitung laba yang diperoleh perusahaan dalam satu periode tertentu.

b. Untuk menilai posisi laba perusahaan tahun sebelumnya dengan tahun sekarang.

c. Untuk menilai perkembangan laba dari waktu ke waktu.

d. Untuk menilai besarnya laba bersih sesudah pajak dengan modal sendiri.

e. Untuk mengukur produktivitas seluruh dana perusahaan yang digunakan baik modal pinjaman maupun modal sendiri.

\section{Manfaat Rasio Profitabilitas}

Rasio profitabilitas memiliki manfaat dan tidak hanya bagi pihak pemilik usaha dan manajemen tetapi juga bagi pihak di luar perusahaan. Menurut Kasmir (2019:200) manfaat yang diperoleh adalah untuk:

a. Mengetahui besarnya tingkat laba yang diperoleh perusahaan dalam satu periode.

b. Mengetahui posisi laba perusahaan tahun sebelumnya dengan tahun sekarang.

c. Mengetahui perkembangan laba dari waktu ke waktu.

d. Mengetahui besarnya laba bersih sesudah pajak.

e. Mengetahui produktivitas dari seluruh dana perusahaan yang digunakan baik modal pinjaman maupun modal sendiri.

\section{Jenis-jenis Rasio Profitabilitas}

Sesuai dengan tujuan yang hendak dicapai, terdapat beberapa jenis rasio profitabilitas yang dapat digunakan. Masing - masing jenis rasio profitabilitas digunakan untuk menilai serta mengukur posisi keuangan perusahaan dalam suatu periode tertentu atau untuk beberapa periode. Jenis- jenis rasio profitabilitas yang dapat digunakan adalah:

a. Gross Profit Margin (Rasio Laba Kotor)

Rasio ini menunjukkan laba kotor per rupiah penjualan atau persentase dari penjualan yang menghasilkan laba kotor. Semakin tinggi gross profit margin maka akan semakin baik profitabilitas CV Surya Indah Perkasa tetapi perlu diperhatikan gross profit margin sangat dipengaruhi oleh harga pokok penjualan.

b. Net Profit Margin (Rasio Laba Bersih)

Alat untuk mengukur efektivitas penjualan dalam menghasilkan laba bersih dan menunjukkan persentase laba bersih dari penjualan yang dihasilkan perusahaan. Apabila gross profit margin selama suatu periode tidak berubah sedangkan net profit margin mengalami penurunan berarti biaya meningkat relatif lebih besar daripada peningkatan penjualan.

c. Operating Profit Margin (Rasio Operasi) 
Rasio ini menunjukkan biaya operasi per rupiah penjualan. Perhitungannya adalah dengan membagi biaya pemasaran ditambah biaya administrasi penjualan dan umum dengan hasil penjualan.

d. Return On Equity (Pengembalian atas Modal)

Rasio ini untuk mengukur tingkat hasil pengembalian dari investasi para pemegang saham (pemilik modal).

e. Return On Total Assest (Pengembalian atas Total Aktiva)

Rasio ini adalah untuk mengukur tingkat kemampuan perusahaan menghasilkan laba bersih perusahaan sesudah pajak dari total aktiva yang dipergunakan.

\section{Metodologi}

Berdasarkan sumbernya, maka data yang diperlukan dalam penelitian adalah berupa data primer dan sekunder. Oleh karena itu teknik pengumpulan data yang dilakukan melalui dua cara yaitu sebagai berikut :

1. Observasi Langsung (Field Research), yaitu penelitian yang dilakukan dengan mengadakan penelitian langsung atau terjun langsung kelapangan, baik dengan melakukan pengamatan langsung (Observasi) terhadap masalah yang menjadi objek penelitian dan melakukan wawancara dengan bagian keuangan pada CV Surya Indah Perkasa.

2. Studi Pustaka (Liberary Research), studi Pustaka merupaka suatu metode yang digunakan dalam pengumpulan data dengan mencari informasi-informasi yang dibutuhkan melalui dokumen-dokumen, buku-buku, jurnal dan sumber tertulis lainnya.

Adapun analisis ini dilakukan untuk mengetahui apakah CV Surya Indah Perkasa pada tahun 2020 mengalami peningkatan dibandingkan tahun 2019. Berikut ini merupakan rumus-rumus yang digunakan dalam menghitung rasio Profitabilitas :

1. Gross Profit Margin (Laba Kotor)

Gross Ptofit Margin merupakan perbandingan antara penjualan bersih dikurangi dengan Harga Pokok penjualan dengan tingkat penjualan, rasio ini menggambarkan laba kotor yang dapat dicapai dari jumlah penjualan. Rasio ini dapat dihitung dengan rumus yaitu :

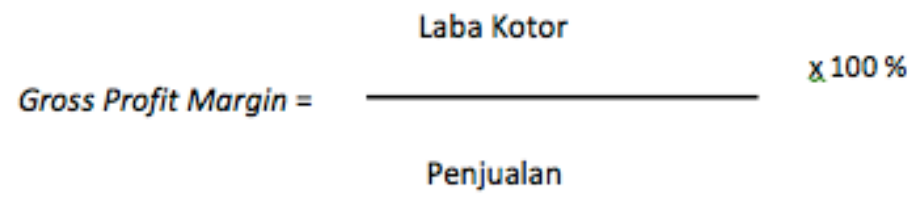

2. Operating Profit Margin (Keuntungan Operasi)

Operating Profit Margin merupakan rasio yang digunakan untuk mengukur seberapa besar kemampuan dalam menghasilkan laba usaha dari penjualan bersih perusahaan selama periode waktu tertentu

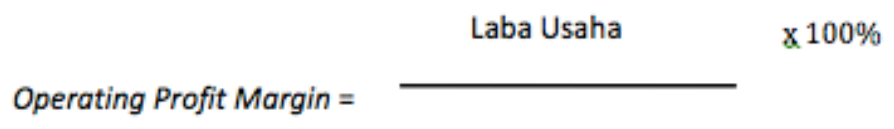

3. Net Profit Margin (Laba Bersih) Penjualan

Net Profit Margin merupakan rasio yang digunakan untuk mengukur laba bersih sesudah pajak lalu dibandingkan dengan volume penjualan. Rasio ini dapat dihitung dengan rumus yaitu : 


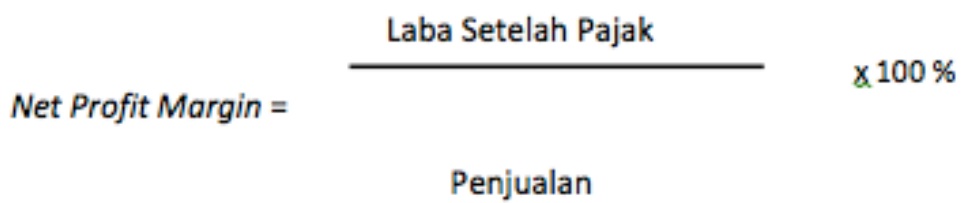

\section{Hasil Pembahasan}

Dari data laporan keuangan laba rugi yang telah disajikan pada bab empat, maka pada bab lima ini peneliti akan menganalisa seberapa besar kemampuan CV Surya Indah Perkasa dalam memperoleh keuntungan. Pengukuran ini berdasarkan pada rasio profitabilitas dalam perhitungan rasio-rasio keuangan tersebut peneliti hanya menggunakan laporan keuangan laba rugi CV Surya Indah Perkasa dua tahun terakhir yaitu tahun 2019 dan 2020.

Perhitungan rasio profitabilitas pada CV Surya Indah Perkasa tahun 2019 dan 2020 adalah sebagai berikut :

\section{Rasio Profitabilitas}

a. Gross Profit Margin (Rasio Laba Kotor)

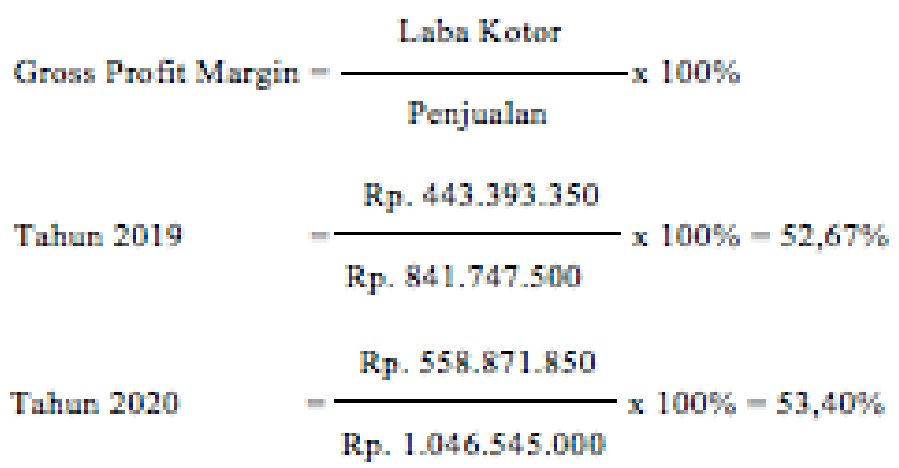

b. Operating Profit Margin (Rasio Laba Usaha)

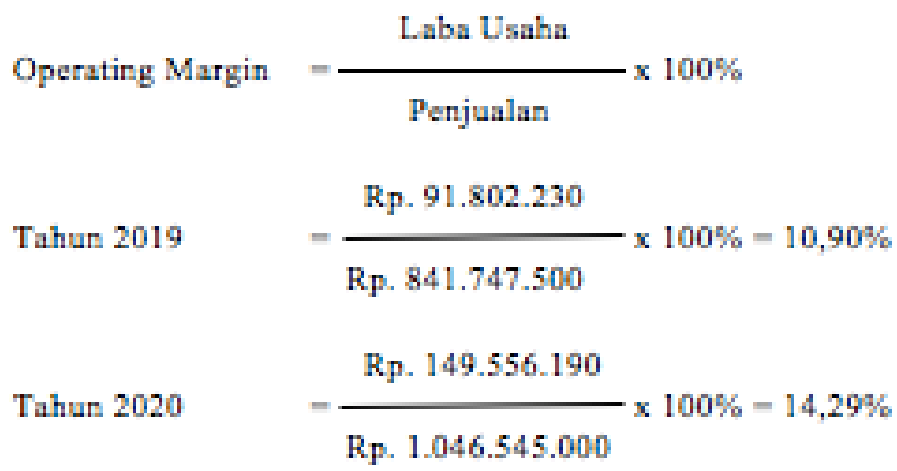

c. Net Profit Margin (Rasio Laba Bersih) 


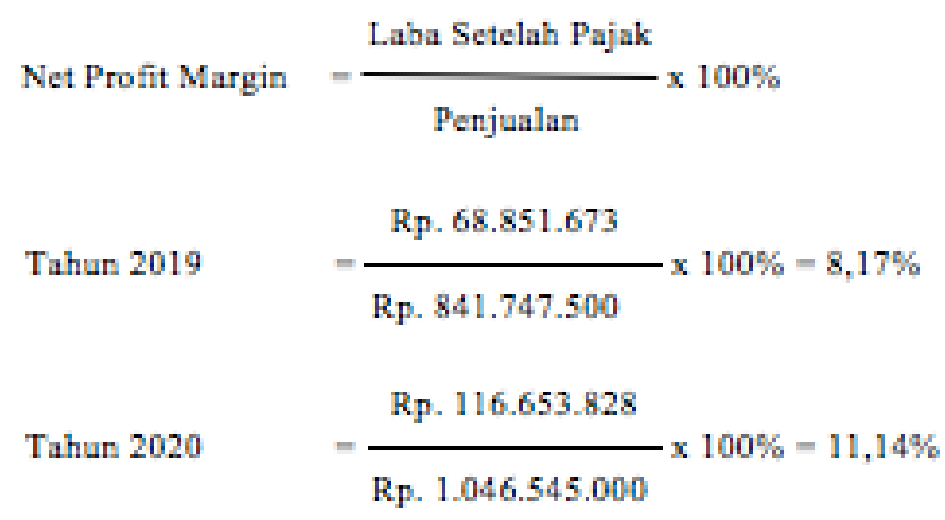

\section{Analisis Common Size}

Analisis common size disusun dengan cara menghitung tiap pos dalam laporan laba - rugi menjadi proporsi dari total penjualan dengan menggunakan rumus :

$$
\text { Common Size Laba Rugi - } \frac{\text { Unsur - unsur RL }}{\text { Penjualan }} \times 100 \%
$$

Pos-pos dalam perhitungan Laba rugi dinyatakan dalam presentase perkomponen atas dasar total penjualan (total penjualan dinyatakan sebesar 100\%). Contoh sebagai berikut :

$$
\begin{aligned}
& \text { Common Size Laba Rugi }-\frac{\text { HPP }}{\text { Penjualan }} \times 100 \% \\
& \text { Tahun } 2019=\frac{\text { Rp. } 398.354 .150}{\text { Rp. } 841.747 .500} \times 100 \%=47,32 \%
\end{aligned}
$$

Namun sebelum masuk ke analisis Common size terlebih dahulu disajikan Analisa trend terhadap laporan laba rugi CV Surya Indah Perkasa sebagai beerikut : 
Tabel 3. Perbandingkan Laba Rugi Tahun 2019 dengan 2020

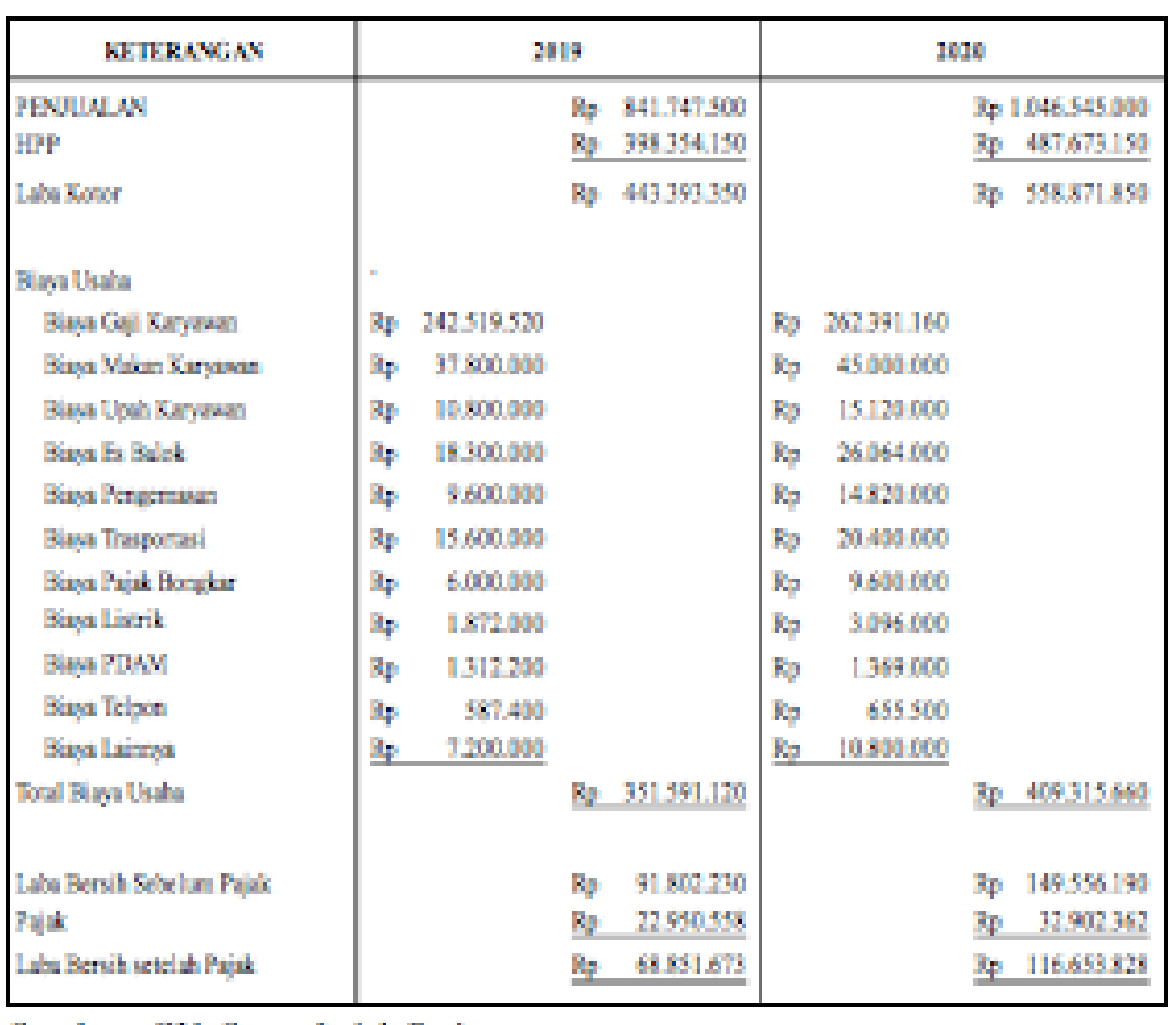

Sumber: CV. Surya Indah Perkasa

Dari tabel analisis trend diatas, maka akan dibuat analisis Common size atas laporan laba rugi CV Surya Indah Perkasa sebagai berikut:

Tabel 4. Analisis Common Size - Laba Rugi \%

\begin{tabular}{|c|c|c|c|}
\hline Keterangan & 2019 & 2020 & $\begin{array}{l}\text { Naik / } \\
\text { Turun }\end{array}$ \\
\hline Penjualan & 100 & 100 & \\
\hline HPP & 47,32 & 46,60 & 0,73 \\
\hline Laba Kotor & 52,68 & 53,40 & 0,73 \\
\hline Bisya Gaji Karyawan & 28,81 & 25,07 & 3,74 \\
\hline Biaya Makan Karyaraan & 4,49 & 4,30 & 0,19 \\
\hline Bisya Upah Karyawun & 1,28 & 1,44 & 0,16 \\
\hline Biaya Es Bslok & 2,17 & 2,49 & 0,32 \\
\hline Biaya Pengemasan & 1,14 & 1,42 & 0,28 \\
\hline Biaya Trasportasi & 1,85 & 1,95 & 0,10 \\
\hline Bisya Pajak Bongkar & 0,71 & 0,92 & 0,20 \\
\hline Bisya Listrik & 0,22 & 0,30 & 0,07 \\
\hline Biaya PDAM & 0,16 & 0,13 & 0,03 \\
\hline Bisya Telpon & 0,07 & 0,06 & 0,01 \\
\hline Bïaya Lainnya & 0,86 & 1,03 & 0,18 \\
\hline Total Biarya Usaha & 41,77 & 39,11 & 2,66 \\
\hline Laba Bersih Sebelum Pajak & 10,91 & 14,29 & 3,38 \\
\hline Pajak & 2,73 & 3,14 & 0,42 \\
\hline Laba Bersih setelah Pajak & 8,18 & 11,15 & 2,97 \\
\hline
\end{tabular}


Untuk mengetahui perkembangan rasio profitabilitas CV Surya Indah Perkasa maka akan membandingkan rasio profitabilitas tahun 2019 dan rasio profitabilitas tahun 2020.

Rekapitulasi hasil perhitungan rasio profitabilitas CV Surya Indah Perkasa Tahun 2019 dan tahun 2020 hasil analisis tersebut dapat dilihat pada tabel 3 dibawah ini :

Tabel 5. Rekapitulasi Perhitungan Rasio Profitabilitas CV Surya Indah

Perkasa Tahun 2019 dan 2020

\begin{tabular}{|l|c|c|c|}
\hline \multirow{2}{*}{ Rasio Profitabilitas } & \multicolumn{2}{|c|}{ Hasil } & \multirow{2}{*}{$\begin{array}{c}\text { Meningkat/ } \\
\text { Menurun }\end{array}$} \\
\cline { 2 - 4 } & $\mathbf{2 0 1 9}$ & $\mathbf{2 0 2 0}$ & $0,67 \%$ \\
\hline Gross Profit Margin & $52,67 \%$ & $53,40 \%$ & $0,39 \%$ \\
\hline Operating Profit Margin & $10,90 \%$ & $14,29 \%$ & $3,39 \%$ \\
\hline Net Profit Margin & $8,17 \%$ & $11,14 \%$ & $2,97 \%$ \\
\hline
\end{tabular}

Sumber : Hasil Analisis Laporan Keuangan CV Surya Indah Perkasa

Pada tahun 2019 gross profit margin CV Surya Indah Perkasa adalah terhitung sebesar 52,67\% artinya bahwa dari setiap penjualan sebesar Rp. 1.000.000,mempu menghasilkan laba kotor bagi suatu perusahaan sebesar Rp. 526.700,- atau bisa juga diartikan bahwa kemampuan perusahaan menghasilkan laba kotor adalah sebesar 52,67\% dari jumlah penjualan yang dicapai sedangkan tahun 2020 gross profit margin CV Surya Indah Perkasa sebesar 53,40\% yang berarti bahwa setiap penjualan perusahaan tersebut sebesar Rp. 1.000.000,- mampu menghasilkan laba kotor sebesar Rp. 534.000,- diartikan kemampuan menghasilkan laba kotor 53,40\% dari jumlah penjualan yang dicapai.

Jika di bandingkan antara gross profit margin tahun 2019 dengan tahun 2020 maka gross profit margin tahun 2020 mengalami peningkatan sebesar 0,67\% ini menunjukkan kemampuan perusahaan pada tahun 2020 untuk menghasilkan laba kotor dari setiap nilai penjualan yang dicapainya mengalami peningkatan sebesar $0,67 \%$ dibandingkan tahun 2019. Peningkatan gross profit margin ini pada dasarnya dikarenakan pada tahun 2020 rasio atau presentasi harga pokok penjualan (harga pokok penjualan : penjualan bersih) mengalami penurunan sebesar $0,73 \%$ dimana pada tahun 2019 sebesar 47,32\% sedangkan tahun 2020 sebesar 46,60\% ini menunjukkan bahwa efisiensi kegiatan operasional perusahaan pada tahun 2020 mengalami perbaikan atau peningkatan yang lebih baik dibandingkan tahun 2019 .

Operating profit margin CV Surya Indah Perkasa untuk tahun 2019 adalah sebesar 10,90\% yang berarti bahwa dari setiap penjualan sebesar Rp. 1.000.000,perusahaan mampu menghasilkan laba sebelum pajak sebesar Rp. 109.000,- atau dapat diartikan bahwa perusahaan memperoleh laba sebelum pajak sebesae 10,90\% dari setiap penjualan yang dicapainya sedangkan untuk tahun 2020 operating profut margin CV Surya Indah Perkasa sebesar 14,29\% berarti setiap Rp. 1.000.000,penjualan mampu mengasilkan laba sebelum pajak sebesar Rp.142.900,- jika 
dibandingkan operating profit margin pada tahun 2019 dengan tahun 2020 maka operating profit margin pada tahun 2020 mengalami peningkatan sebesar 3,39\%.

Peningkatan operating profit margin tahun 2020 dibandingkan tahun 2019 pada CV Surya Indah Perkasa menurut Analisa peneliti dipengaruhi oleh kemampuan manajemen dalam mengoptimalkan penggunaan sumber daya yang dimiliki perusahaan (efisiensi biaya-biaya usaha). Kenaikan operating profit margin tahun 2020 ini menandakan bahwa perusahaan mampu meningkatkan penjualan dan meminimalkan biaya-biaya. Dengan operating profit margin yang meningkat berarti perusahaan memiliki manajemen yang baik dalam meminimalkan biaya dalam operasi yang dijalankannya sehingga perusahaan dapat menghasilkan laba yang lebih tinggi dibandingkan tahun sebelumnya.

Net profit margin CV Surya Indah Perkasa untuk tahun 2019 adalah sebesar $8,17 \%$ yang berarti bahwa dari setiap penjualan sebesar Rp. 1.000.000,- perusahaan mampu menghasilkan laba bersih setelah pajak sebesar Rp. 81.700,- atau bisa juga diartikan bahwa perusahaan memperoleh laba bersih setelah pajak sebesar $8,17 \%$ dari setiap jumlah penjualan yang dicapainya. Sedangkan untuk tahun 2020 net profit margin CV Surya Indah Perkasa adalah sebesar 11,14\% berarti bahwa setiap Rp. 1.000.000,- penjualan mampu menghasilkan laba bersih setelah pajak sebesar Rp. 111,400,-. Jika dibandingkan net profit margin pada tahun 2019 dengan tahun 2020 maka net profit margin pada tahun 2020 mengalami peningkatan sebesar 2,97\%.

Peningkatan net profit margin tahun 2020 dibandingkan tahun 2019 pada CV Surya Indah Perkasa menurut Analisa peneliti dipengaruhi oleh adanya efektivitas pencapaian target penjualan (peningkatan penjualan) dan kegiatan operasi perusahaan yang dilakukan secara efisien. Dengan meningkatnya rasio ini tentunya harus lebih memotivasi pihak manajemen untuk bekerja lebih giat dalam usaha meningkatkan kinerja perusahaan karena dengan semakin meningkatnya net profit margin maka menunjukkan bahwa kinerja perusahaan tersebut semakin baik melalui efektivitas dan efisien kegiatan-kegiatan operasional sehingga keuntungan perusahaan dapat lebih meningkat lagi dibandingkan sebelumnya.

\section{PENUTUP}

\section{Kesimpulan}

Berdasarkan hasil Analisis dan pembahasan yang telah dikemukakan maka ada dua hal yang dapat peneliti simpulkan yaitu :

1. Tingkat kemampuan CV Surya Indah Perkasa dalam menghasilkan laba berdasarkan rasio profitabilitas untuk tahun 2020 dibandingkan tahun 2019 mengalami peningkatan yang artinya hipotesis yang peniliti ajukan diterima. Hal ini sesuai dengan hasil analisis diketahui secara keseluruhan rasio profitabilitas CV Surya Indah Perkasa mengalami peningkatan dimana gross profit margin meningkat sebesar $0,67 \%$, operating profit margin meningkat sebesar 3,39\%, dan net profit margin meningkat sebesar $2,97 \%$.

2. Peningkatan Rasio ini dipengaruhi oleh beberapa hal yaitu Gross Profit Margin meningkat dikarenakan terjadinya efisiensi biaya-biaya operasional yang dilakukan pihak manajemen perusahaan, Operating Profit Margin meningkat dikarenakan kemampuan manajemen perusahaan yang baik dalam mengoptimalkan penggunaan sumber daya yang dimiliki perusahaan dan $\mathrm{Net}$ Profit Margin meningkat dikarenakan terjadinya efektivitas dalam pencapaian target penjualan atau peningkatan dalam penjualan. 


\section{Saran} berikut:

Saran yang dapat peneliti kemukakan dari hasil kesimpulan diatas sebagai

1. Perusahaan CV Surya Indah Perkasa hendaknya melakukan pemantau yang ketat terhadap pelaksanaan pengeluaran biaya kegiatan operasional perusahaan sebagai efisiensi keuangan perusahaan dan melakukan penyimpanan data dengan baik sehingga tidak terjadi kekurangan dalam data.

2. Perusahaan CV Surya Indah Perkasa perlu mengoptimalkan penjualan perusahaan sehingga laba yang diperoleh perusahaan dapat lebih meningkat lagi disetiap tahunnya dengan cara menjalin relasi lebih banyak dengan para petambak.

\section{DAFTAR RUJUKAN}

Fahmi. 2014. Pengantar Manajemen Keuangan : Teori dan Soal Jawab, Alfabeta, Bandung.

Harahap. 2018. Analisis Kritis Atas Laporan Keuangan, Edisi Pertama Cetakan ke-14. Rajawali Pers, Depok.

Hasibuan. 2012. Manajemen Sumber Daya Manusia, Cetakan Keenam Belas. Bumi Aksara, Jakarta.

Horne dan Wachowicz. 2012. Prinsip-Prinsip Manajemen Keuangan Fundamentals of Financial Management, Edisi 13 Buku 1. Salemba Empat, Jakarta.

JavanLabs. 2015-2021. https://tafsirq.com/46-al-ahqaf/ayat-19, diakses tanggal 22 Mei 2021

Kasmir. 2019. Analisis Laporan Keuangan Edisi Revisi, Cetakan ke-12. Rajawali Pers, Depok.

MNC Media. https://kalam.sindonews.com/ayat/18/59/al-hasyr-ayat-18 diakses tanggal 22 Mei 2021

Munawir. 2014. Analisa Laporan Keuangan, Edisi Keempat Cetakan Ketujuhbelas. Liberty, Yogyakarta.

Musthafa. 2017. Manajemen Keuangan, Cetakan Pertama. Penerbit ANDI, Yogyakarta.

Sulastri. 2014. Manajemen Sebuah Pengantar Sejarah, Tokoh, Teori dan Praktik, Cetakan Ketiga. La Goods Publishing, Bandung.

Sutrisno. 2013. Manajemen Keuangan Teori, Konsep dan Aplikasi, Cetakan Kesembilan. EKONISA FK UII, Yogyakarta.

Terry GR. 2010. Dasar-Dasar Manajemen, Cetakan kesebelas. Bumi Aksara, Jakarta.

Wijaya, Candra dan M. Rifai. 2016. Dasar-Dasar Mengoptimalkan Organisasi Secara Efektif dan Efisien, Cetakan Pertama. Perdana Publishing, Medan. 